\title{
Detection of Perianal Horseshoe Fistula with Endoanal Ultrasound: Video Presentation
}

\section{Endoanal Ultrasonografi ile Perianal Atnalı Fistül Tespiti: Video Sunum}

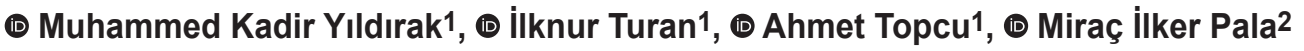 \\ ${ }^{1}$ University of Health Sciences Turkey, Ümraniye Training and Research Hospital, Clinic of General Surgery, İstanbul, Turkey \\ 2istanbul Medipol University Faculty of Medicine, Department of General Surgery, İstanbul, Turkey
}

\section{HIIIIII ABSTRACT}

Today, the horseshoe fistulas are counted among the most difficultly managed perianal fistula types. This entity, which is regarded as one of a complex fistula type, affects the ischioanal fossa. Its treatment is more costly and the optimal surgical intervention required is more complex. Since it can affect more than one anatomical structure, chance of treatment failure, perioperative and postoperative complication rates and recurrence rates increase. Especially insufficient preoperative assessment leads in most cases to devastating outcomes for both the physician and the patient. Horseshoe fistulas can be diagnosed easily with magnetic resonance imaging, which is a common modality used in evaluating perianal fistulas. However, due to the high cost and dependance on an experienced radiologist for interpretation in common practice, endoanal ultrasonography (USG) has started to gain popularity. Ability of assessing the perianal anatomy and especially the sphincter complex properly just prior to surgery in operating theatre comprise the most prominent advantages of endoanal USG. In this video presentation, we aimed to show the endoanal USG images of a horseshoe fistula tract following the injection of hydrogen peroxid solution with a branule in the perianal fistula tract of a patient with a history of Crohn's disease.

Keywords: Complex perianal fistula, endoanal USG, horseshoe fistula

\section{|IIIIIIII| ÖZ}

Günümüzde yönetimi en zor olan perianal fistül çeşitlerinden biri de atnalı fistüllerdir. Kompleks fistüller kategorisinde değerlendirilen bu hastalık işioanal fossayı etkilemekte olup tedavisi daha maliyetli ve gereken optimal cerrahi girişimi daha komplekstir. Birden fazla anatomik yapıyı etkileyebilmesi nedeni ile tedavi başarısızlığı, peroperatif ve postoperatif komplikasyon oranlarının artması, rekürrens oranının yüksek olması ve özellikle yetersiz preoperatif değerlendirme sonucu hem hekim hem de hasta yönünden ciddi negatif sonuçlar doğabilmektedir. Perianal fistüllerde sık kullanılan bir modalite olan MR ile atnalı fistüllerin tanısı rahatlıkla konabilmektedir. Ancak maliyetin yüksek olması ve çoğunlukla yorum için bir radyoloğa ihtiyaç duyulması nedeni ile endoanal ultrasonografi (USG) son zamanlarda klinik uygulamaya daha çok girmeye başlamıştır. Endoanal USG'nin en önemli avantajları arasında ameliyat masasında eş zamanlı perianal bölge anatomisinin ve özellikle sfinkterlerin optimal şekilde değerlendirilebilmesi söylenebilir. Bu video prezentasyonda crohn hastalığı öyküsü olan bir hastada atnalı fistül traktının intraket ile oksijenli su enjeksiyonunu takiben endoanal USG görüntüsünün paylaşılması amaçlanmıştır.

Anahtar Kelimeler: Kompleks perianal fistül, endoanal USG, atnalı fistül

\section{Introduction}

One of the most important diseases affecting the perianal region is perianal fistula. The incidence of this disease in the population is $2 \%$, and it is three times more common in men than in women. The typical features are that it has a chronic course, the rate of spontaneous remission is very low, recurrence is common, and it usually requires at least one surgical intervention. ${ }^{1}$ It should not be forgotten that apart from the emotional and physical distress caused, perianal fistula also leads to severe loss working capability and the diagnosis and treatment may be costly. Perianal fistula may be divided into two groups; complex and non-complex

Address for Correspondence/Yazışma Adresi: Muhammed Kadir Yıldırak, MD,

University of Health Sciences Turkey, Ümraniye Training and Research Hospital, Clinic of General Surgery, İstanbul, Turkey

E-mail: kadiryildira@gmail.com ORCID ID: orcid.org/0000-0002-6241-5661

Received/Geliş Tarihi: 04.02.2021 Accepted/Kabul Tarihi: 25.03.2021

${ }^{\circ}$ Copyright 2021 by Turkish Society of Colon and Rectal Surgery

Turkish Journal of Colorectal Disease published by Galenos Publishing House. 
fistulas with complex fistula being more challenging for clinical management. The delay in the diagnosis of a complex fistula, which includes horseshoe fistula, or the inability to perform optimal surgery as a result of inadequate preoperative evaluation, may result in the development of sepsis, incontinence secondary to progressive destruction, and eventually permanent stoma. In the classical approach, preoperative magnetic resonance imaging (MRI) evaluation is considered superior to other methods because MRI can provide optimal quality images and sufficient information for the evaluation of pelvic floor anatomy in the diagnosis of perianal fistula. However, MRI is not available everywhere, it can be costly and interpretation is dependent of the experience of the radiologist. Especially in high-volume centers, the delay between the MRI scan and the operation date may causs the patient to be operated without adequate evaluation of disease progression or inadequate identification and assessment of any newly developed complication. In modern practice, physical examination is recommended for the diagnosis of noncomplex fistulas and no other method is necessary. ${ }^{2}$ In complex, recurrent or Crohn-related fistulas, endoanal ultrasonography (USG) is currently preferred because of the low cost and ease of application before surgery. In this video presentation, the aim was to share the endoanal USG image of a horseshoe fistula tract following the injection of oxygenated water with an intraket in a 34-year-old male patient with a nine-year history of Crohn disease who was actively using azathioprine and infliximab. Written informed consent was obtained from the patient. After sedoanalgesia, the patient was placed in the lithotomy position. The external mouth of the fistula at the 7 o'clock position was visualized from $3 \mathrm{~cm}$ distal to the ancutaneous line. Since the inner mouth could not be visualized clearly during anal exploration, it was decided to perform endoanal
USG. The patient was placed in the left lateral decubitus position. An endoanal USG probe (Anorectal 3D 2052, BK Medical) with a frequency of $16-6 \mathrm{MHz}$ was placed in the anal canal. Oxygenated water was introduced into the tract through an intraket. The fistula tract was detected by USG and the procedure was terminated.

In conclusion, this presentation has demonstrated that an endoanal USG examination may be performed before surgery on the operating table and is a cheap, easily applicable and effective method. This can be used to ensure provision optimal treatment for patients with complex or recurrent perianal fistula.

*This video presentation was recorded at the proctology course held at University of Health Sciences Turkey Ümraniye Training and Research Hospital on 17.10.2020.

\section{Ethics}

Informed Consent: Obtained.

Peer-review: Externally peer reviewed.

\section{Authorship Contributions}

Surgical and Medical Practices: M.İ.P., İ.T., Concept: M.İ.P., Design: A.T., Data Collection or Processing: M.K.Y., Analysis or Interpretation: A.T., Literature Search: M.K.Y., İ.T., Writing: M.K.Y., A.T.

Conflict of Interest: No conflict of interest was declared by the authors.

Financial Disclosure: The authors declared that this study received no financial support.

\section{References}

1. Herold A, Lehur P, Matzel KE and O'Connell PR. Coloproctology, 2nd ed. Berlin, Germany: Springer; 2017;59-73.

2. Steele SR, Hull TL, Read TR, Saclarides TJ, Senagore AJ and Whitlow CB. The ASCRS Textbook of Colon and Rectal Surgery, 3th ed. Arlington Heights, IL, USA: Springer; 2016;215-244.

Video 1.

https://www.doi.org/10.4274/tjcd.galenos.2021.2021-1-13.video1 